\title{
Use of natural bio-sorbent in removing dye, heavy metal and antibiotic-resistant bacteria from industrial wastewater
}

\author{
Sunzid Ahmed ${ }^{1} \cdot$ Salma Aktar $^{2} \cdot$ Sharmin Zaman $^{1} \cdot$ Rumana Akther Jahan $^{1} \cdot$ Md. Latiful Bari $^{1}$
}

Received: 6 September 2019 / Accepted: 3 April 2020 / Published online: 15 April 2020

(c) The Author(s) 2020

\begin{abstract}
In this study, we evaluated the ability of waste shell powder (WSP) and moringa seed powder (MSP) individually or in combination to eliminate dye, heavy metal and resistant bacteria from the industrial wastewater (IWW). The presence of dyes, heavy metals, approximately $7.0 \mathrm{log}$ CFU/ml of aerobic bacteria and 3.0-4.0 log CFU/ml of other pathogens including Escherichia coli, Pseudomonas aeruginosa, Citrobacter freundii, Serratia liquefaciens and Bacillus cereus was evident in IWW of both tannery and textile industries. In addition, depending on the type of bacterial species each bacterium was resistant to as high as $50 \mathrm{ppm}$ of multi-metal $\left(\mathrm{Cr}^{6+}, \mathrm{Cd}^{2+}\right.$ and $\mathrm{Pb}^{2+}$ or its combination) and even multi-drug resistant (amoxicillin, ampicillin, cefixime, ceftazidime, and tazobactam). Combined use of MSP $(0.8 \mathrm{gm} / 100 \mathrm{ml}$ IWW $)$ and WSP $(0.2 \mathrm{gm} / 100 \mathrm{ml}$ IWW) treatment was able to discolor the IWW within $4 \mathrm{~h}$ and took $24 \mathrm{~h}$ to eliminate heavy metals and pathogenic bacteria to non-detectable level from the IWW, simultaneously. On the other hand, individual use of MSP or WSP was not found effective enough to remove or eliminate dye, heavy metal and bacteria simultaneously from the IWW. Similar experimental results were observed in the challenge test with laboratory-prepared effluent water containing 35.0 ppm Remazol Brilliant Blue $\mathrm{R}$ dye and maximum $50 \mathrm{ppm} \mathrm{Cr}^{6+}$. Thus, the combination of these two bio-sorbents could be applicable in IWW treatment before being discharged into the environment.
\end{abstract}

Keywords Industrial effluent water $\cdot$ Multi-drug-resistant bacteria $\cdot$ Discoloration $\cdot$ Heavy metal $\cdot$ And natural bio-sorbents

\section{Introduction}

Many industries such as textile, paper and plastics use dyestuffs in order to color their products and also consume substantial volumes of water (Rodrigues et al. 2013). As a result, they generate a considerable amount of colored wastewater (Kant 2012). It is recognized that public perception of water quality is greatly influenced by the color which is the first contaminant to be recognized with open eyes in wastewater (Alalewi and Jiang 2012). The presence of very small amounts of dyes in water (less than $1.0 \mathrm{ppm}$ for some dyes) is highly visible and undesirable (Dorthy et al. 2012). On the other hand, the presence of heavy metals in industrial effluents is known to have major hazard to

Md. Latiful Bari

latiful@du.ac.bd

1 Center for Advanced Research in Sciences, University of Dhaka, Dhaka 1000, Bangladesh

2 Department of Microbiology, Noakhali Science and Technology University, Noakhali 3814, Bangladesh natural water, animal and human health (Ezaka and Anayanwu 2011; Girma 2015).

High concentrations of all heavy metals have deleterious effect on the environment (Akpor and Muchie 2010; Wang et al. 2014). Toxic heavy metals like mercury $\left(\mathrm{Hg}^{2+}\right)$, chromium $\left(\mathrm{Cr}^{6+}\right)$, lead $\left(\mathrm{Pb}^{2+}\right)$ and cadmium $\left(\mathrm{Cd}^{2+}\right)$ have no biological role, but they are well known for their toxicities, mutagenicity and carcinogenic impacts on human beings and other aquatic living system especially those metals classified under priority list of pollutants (Akpor and Muchie 2010; Abbas et al. 2014; Girma 2015). Untreated industrial wastewater discharged to the nearby water bodies may cause severe ground water pollution (Pandey et al. 2007). However, wastewater containing dyes is very difficult to treat, since the dyes are recalcitrant organic molecules, resistant to aerobic digestion, and stable to light, heat and oxidizing agents (Islam et al. 2011; Priya and Selvan 2017). Although several new composite materials including polyphenylsulfone or multi-walled carbon nanotubes membrane filters (Nayak et al. 2019), graphene oxide-based nano-materials (Lim et al. 2018) and selective composite 
cation exchanger (Ismail 2010; Nabi et al. 2011) have been developed, however, commonly used procedures for removing metal ions from aqueous streams include chemical precipitation, lime coagulation, ion exchange, reverse osmosis and solvent extraction (Kant 2012; Patel et al. 2013). During the past three decades, several physical, chemical and biological discoloration methods have been reported (Oak et al. 2016); however, few have been accepted by the paper and textile industries. Although some of these techniques have been shown to be effective, they have limitations as well (Hou et al. 2016). Among these, excess amount of chemical usage or accumulation of concentrated sludge with obvious disposal problems; expensive plant requirements or operational costs; lack of effective color reduction; and sensitivity to a variable wastewater input were notably mentioned (Padhi 2012). In view of these disadvantages, bio-sorption or removal of heavy metals, dyes and resistant pathogens by biological materials has gained momentum since naturally occurring biomass/adsorbents or spent biomass can be effectively used (Ali et al. 2009; Aho and Lagasi 2012; Eze and Ananso 2014).

Moringa seed powder (MSP) is a natural coagulant and has antimicrobial properties and absorption capacity that have been tested over the years as an alternative to the use of inorganic and synthetic coagulants, antimicrobials and absorbents (Valverde et al. 2018; Taiwo et al. 2020). Moringa oleifera is a sustainable, low-cost, locally available, simple, reliable, acceptable, eco-friendly and householdlevel point of used water treatment coagulant/technology most suitable for developing countries (Zaman et al. 2017). Advantages of MSP are it produces lesser volume of biodegradable sludge and it does not affect the physicochemical quality of the water. Despite a strong natural coagulant, moringa seed extract also acts as potential adsorbent and antimicrobial agent and has the capability of adsorbing $95 \%$ of copper, $93 \%$ of lead, $76 \%$ of cadmium and $70 \%$ of chromium, from water. Metal adsorption occurs due to the high protein content of the seeds, and the flocculation activities of MSP are based on the electrostatic patch charge mechanism. Studies have shown that seeds have the capability to adsorb metal cations and attract highly toxic compounds (Ravikumar and Sheeja 2013).

On the other hand, heated waste shell powder (WSP) has widely been used for killing pathogens and fungus in many environmental samples (Ahmed et al. 2015; Hou et al. 2016; Zaman et al. 2017). Shell powder heated to over $700{ }^{\circ} \mathrm{C}$ exhibited a bactericidal activity (Sawai et al. 2003). Likewise, scallop shells are reused in forestry road construction, as absorbent for phosphate (Jeon and Yeom 2009). Thus, heated waste shell possesses adsorbent capabilities to remove heavy metals (Ravikumar and Sheeja 2013), microorganisms or other impurities from the liquid (Sawai et al. 2003; Ahmed et al. 2017). Shell waste is a growing burden for seafood industries, and shells piled up near the seaside create several problems such as emission of offensive odors and soil pollution of heavy metals (Sawai et al. 2003). Thus, ideal solution was thought to convert the waste shells into a product that is both environmentally beneficial and economically feasible. In addition, combination of these two natural materials was thought to discolor dye, absorb metal and eliminate pathogens from the wastewater effluent. Therefore, the present study was designed to evaluate the effectiveness of two naturally occurring biomass (MSP and WSP) singly or in combination could completely eliminate heavy metals and microorganisms, as well as discolor the effluent water simultaneously.

\section{Methods and materials}

\section{The industrial wastewater (IWW)}

The effluent wastewater samples of tannery and textile industries were collected from the outlets of the industries at Hazaribagh and Uttara area of Dhaka city, Bangladesh. The sample collection was carried out at about 12:00 $\mathrm{h}$ and the peak production time for the industries observed. The effluent wastewater $(500 \mathrm{ml})$ was collected in dark brown plastic bottles from the discharge point of both tannery and textile industries and transported to the laboratory in a cool box within $2 \mathrm{~h}$ of collection and used; if not used immediately, the samples were kept at $25{ }^{\circ} \mathrm{C}$ in dark until using.

\section{Measurement of physicochemical parameters}

Physicochemical parameters including temperature, $\mathrm{pH}$, total dissolved solid (TDS), conductivity, salinity and heavy metals content of the wastewater samples were analyzed and recorded. Both the treated and non-treated effluent wastewater samples were analyzed periodically using $\mathrm{pH}$ meter (BT 600, Boeco, Germany), handy TDS meter (HI98301, Hanna, Italy), water conductivity tester (COND502, Taiwan), digital pen salinity meter (AZ8371, China) and atomic absorption spectrometer (AAS, Shimadzu, Japan) according to the manufacturers' instruction.

\section{Preparation of bio-sorbant materials}

Heated waste shell powder was obtained from ICHIBAN LIFE CORP., Tokyo, Japan. For the preparation of seed powder, moringa seeds were collected from the mature raw fruits and then dried in an oven at $50-60{ }^{\circ} \mathrm{C}$ temperature for $48 \mathrm{~h}$ before grinding the dried seeds in mortar-pestle and then sieved with 50-micron mesh to collect the fine powder. These ingredients at different dose rates 
were used singly or in combination to evaluate the effectiveness of the ingredients responsible in discoloration and/or reduction of heavy metal(s) in textile and tannery effluent water.

\section{Microbiological analysis}

For the determination of resident microorganisms and for isolating the heavy metal-resistant resident and pathogenic bacteria in treated and untreated IWW, various selective and non-selective agar media supplemented with $50 \mathrm{ppm}$ of $\mathrm{Cr}^{6+}, \mathrm{Pb}^{2+}$ and $\mathrm{Cd}^{2+}$ was surface-plated. All the reagents and chemicals were prepared individually and sterilized before being used in the experiment. Tryptic soya agar (Oxoid, England) was used for the isolation of total aerobic bacteria (TAB), where total coliform bacteria (TCB), Escherichia coli and Citrobacter freundii were isolated on Chromocult agar (Merck, Germany). Bismuth sulfite agar (Oxoid, England) and cetrimide agar (HiMedia, India) were in use for the isolation of Serratia liquefaciens and Pseudomonas aeruginosa, respectively. After inoculation, all the plates were incubated at $30-35{ }^{\circ} \mathrm{C}$

\section{Discoloration assay of IWW}

Four 250-ml beakers each containing $150 \mathrm{ml}$ of IWW and various doses WSP and MSP were added separately in three separate combinations (only heated waste shell powder (WSP), only moringa seed powder (MSP) and combination of WSP and MSP) and stirred using glass rod for $20 \mathrm{~s}$ and left at room temperature until clear solution was observed. Non-treated (no biocide was added) beaker was served as control. Discoloration activity was expressed in terms of percentage discoloration and was determined by observing the decrease in absorbance at $200-500 \mathrm{~nm}$ of wavelength respective dyes. To examine the dye concentration, $3 \mathrm{ml}$ of sample was centrifuged at 13,000 rpm for $15 \mathrm{~min}$ and the absorbance values of supernatants were determined at $200-500 \mathrm{~nm}$ of wavelength. The degree of discoloration of the tested dye was measured at its respective maximum absorbance wavelength using supernatant by UV-visible spectrophotometer (1800, Shimadzu, Japan). The rate of discoloration of MSP and WSP was calculated using the following formula:

Discoloration ability $(\%)=\frac{\text { Initial absorbance of combinations }- \text { absorbance after combinations }}{\text { Initial absorbance of combinations }} \times 100$

for 24-72 $\mathrm{h}$ before being counted. At least five randomly selected colonies of each bacterium were confirmed through API 20E, 20NE, 50 CHB (BioMurex, USA) and other biochemical tests.

\section{Laboratory-prepared heavy metal solution}

Heavy metal solution prepared in the laboratory individually; both of the $2.0 \mathrm{ppm}$ and $50 \mathrm{ppm} \mathrm{Cr}$ solution were prepared from the $100 \mathrm{ppm}$ stock solution of $\mathrm{K}_{2} \mathrm{Cr}_{2} \mathrm{O}_{7}$ (Active Fine Chemicals Ltd, Bangladesh).

\section{Antibiotic resistivity}

The randomly selected heavy metal-resistant bacterial isolates were subjected to the Kirby-Bauer disc diffusion susceptibility test with 14 broad spectrum antibiotics (chloramphenicol, $30 \mu \mathrm{g}$; ciprofloxacin, $5 \mu \mathrm{g}$; tetracycline, $30 \mu \mathrm{g}$; and nitrofurantoin, $300 \mu \mathrm{g}$; amoxicillin, $10 \mu \mathrm{g}$; rifampicin, $5 \mu \mathrm{g}$; azithromycin, $15 \mu \mathrm{g}$; ceftazidime, $30 \mu \mathrm{g}$; cefixime, $5 \mu \mathrm{g}$; streptomycin, $10 \mu \mathrm{g}$; erythromycin, gentamycin, $10 \mathrm{ug} ; 15 \mu \mathrm{g}$; tazobactam, $110 \mu \mathrm{g}$; and ampicillin, $10 \mu \mathrm{g}$ ) and six short spectrum antibiotics (nalidixic acid, $30 \mu \mathrm{g}$; kanamycin, $30 \mu \mathrm{g}$; bacitracin, $10 \mu \mathrm{g}$; aztreonam, $30 \mu \mathrm{g}$; novobiocin, $30 \mu \mathrm{g}$; and polymyxin, $300 \mu \mathrm{g}$ ) to determine the resistivity or sensitivity.

\section{Determination of heavy metal in IWW}

For the determination of residual heavy metal $\left(\mathrm{Cr}^{6+}\right)$ in the treated effluent water, clear water was taken from the upper layer and filtered through $0.45 \mu \mathrm{m}$ filter paper and the hexavalent $\mathrm{Cr}^{6+}$ and $\mathrm{Cr}^{3+}$ contents in the filtered water were measured using the diphenylcarbazide-based $\mathrm{Cr}^{6+}$ and $\mathrm{Cr}^{3+}$ test kits (Kyoritsu, Japan).

\section{Laboratory-prepared dye containing low level of $\mathrm{Cr}^{6+}$ content (challenge test)}

Each $150 \mathrm{ml}$ of test solution was containing $35.0 \mathrm{ppm}$ dye solutions (prepared from a $100 \mathrm{ppm}$ Remazol Brilliant Blue $\mathrm{R}$ stock solution) and 2 and/or $50 \mathrm{ppm} \mathrm{Cr}^{6+}$ content (prepared from $100 \mathrm{ppm} \mathrm{K}_{2} \mathrm{Cr}_{2} \mathrm{O}_{7}$ stock solution). WSP and MSP or its combinations were added in separate beaker and stirred for $20 \mathrm{~s}$ using glass rod and left at room temperature until discoloration was completed. Non-treated (no biocide was added) beaker was served as control. Discoloration ability was expressed in terms of percentage discoloration and was determined by observing the decrease in absorbance at $200-500 \mathrm{~nm}$ of respective dyes as described in the previous section.

The low-level hexavalent $\mathrm{Cr}^{6+}$ content of treated and nontreated dye solutions was determined using diphenylcarbazide

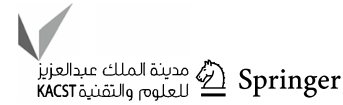


color comparison method-based test kits (Kyoritsu, Japan). The clear solutions from the top of each beaker were filtered through Whatman filter paper, and then, total $\mathrm{Cr}^{3+}$ and $\mathrm{Cr}^{6+}$ (WAK-Cr T, Kyoritsu, Japan) content and hexavalent $\mathrm{Cr}^{6+}$ (WAP-Cr ${ }^{6+}$, Kyoritsu, Japan) contents were checked periodically. The detection limits of total $\mathrm{Cr}^{6+}$ kit were $0.5-50 \mathrm{mg} / \mathrm{L}$, and hexavalent $\mathrm{Cr}^{6+}$ kit was $0.05-2.0 \mathrm{mg} / \mathrm{L}$, respectively.

\section{Statistical analysis}

Each category of effluent water was collected three times in a week from the same industries effluent outlet. Reported data for all parameter tested represent the mean values obtained from three individual trials, with each of these values being obtained from duplicated samples. Data were subjected to analysis of variance using the Microsoft Excel program (Redmond, Washington DC, USA). Significant differences in data were established by the least significant difference at the $5 \%$ level of significance.

\section{Results and discussion}

The presence of dye, heavy metals and resistant microorganisms in industrial effluents is known to have major hazards to natural habitat. High concentrations of dye and heavy metals have deleterious effect on the environment, and hence, it is necessary to eliminate these from industrial wastewater (IWW) before it is discharged to the environment (Wang et al. 2014). Various physical, chemical and biological technologies for treating these industrial effluents exist (Sajidu et al. 2006). However, physical and chemical technologies got demerits of having membrane logging, short shelf life and periodic replacement of membrane, costly, and create disposal problem (Ravikumar and Sheeja 2013). Adsorption technique for the removal of wide variety of dyes from wastewaters is an ideal alternative to other expensive treatment options (Mangale et al. 2012). In this study, two new natural and eco-friendly ingredients were introduced for effective dye discoloration, heavy metal removal and elimination of pathogens from industrial wastewater. The results revealed that dye discoloration occurs quickly with stirring (150 rpm) within $1 \mathrm{~h}$; however, it takes $4 \mathrm{~h}$ to discolor completely without stirring as shown in Fig. 1. In addition, it was also observed that the dyes discoloration capacity depends on the initial concentration of dyes, contact time and stirring time. Only effective treatment concentration was shown in Fig. 1 .
Fig. 1 Discoloration effects of MSP and WSP on different EWW (a textile IWW; $\mathbf{b}$ tannery IWW; $\mathbf{c}$ challenge test with LPEW)
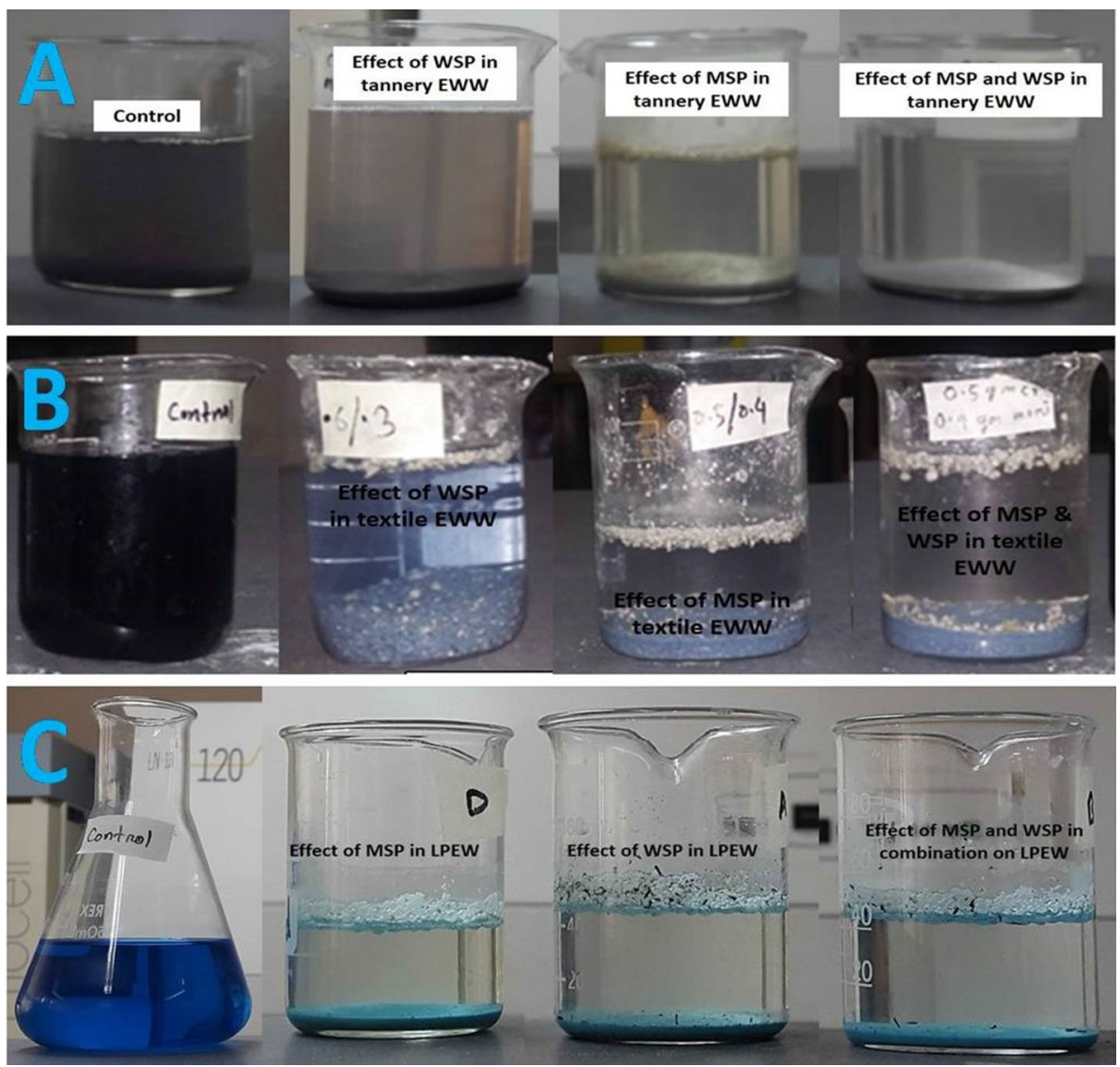
Table 1 Comparison of the physicochemical parameters of textile and tannery EWW with WHO permissible limit

\begin{tabular}{|c|c|c|c|c|}
\hline \multirow{2}{*}{\multicolumn{2}{|c|}{ Physicochemical parameters }} & \multicolumn{2}{|c|}{ Sources of wastewater } & \multirow{2}{*}{$\begin{array}{l}\text { WHO } \\
\text { permissible } \\
\text { limit }\end{array}$} \\
\hline & & Textile & Tannery & \\
\hline \multicolumn{2}{|l|}{ Color } & Dark violet & Deep blue & - \\
\hline \multicolumn{2}{|l|}{$\mathrm{pH}$} & 6.85 & 7.4 & $5.5-9.0$ \\
\hline \multicolumn{2}{|l|}{ BOD (mg/l) } & 164.66 & 4464 & 30 \\
\hline \multicolumn{2}{|l|}{$\mathrm{COD}(\mathrm{mg} / \mathrm{L})$} & 475.35 & 1284 & 250 \\
\hline \multicolumn{2}{|l|}{ TSS (mg/L) } & 1490 & 1250 & 600 \\
\hline \multicolumn{2}{|l|}{ TDS (mg/L) } & 912 & 851 & 2100 \\
\hline \multicolumn{2}{|l|}{ Conductivity $(\mu \mathrm{s} / \mathrm{cm})$} & 1370 & 1430 & 1200 \\
\hline \multicolumn{2}{|l|}{ Salinity (ppt) } & 0.49 & 0.80 & - \\
\hline \multirow[t]{8}{*}{ Metals (mg/L) } & $\mathrm{Fe}^{3+}$ & 1.23 & 14.67 & 10 \\
\hline & $\mathrm{Cu}^{2+}$ & 25.14 & 0.41 & 0.1 \\
\hline & $\mathrm{Zn}^{2+}$ & 49.08 & 1.52 & 1.0 \\
\hline & $\mathrm{Cd}^{2+}$ & 1.9 & 1.26 & 2.0 \\
\hline & $\mathrm{Ni}^{2+}$ & 3.05 & 0.15 & 3.0 \\
\hline & $\mathrm{Pb}^{2+}$ & 18.4 & 0.182 & 0.1 \\
\hline & $\mathrm{Cr}^{6+}$ & 132.5 & 10.35 & 2.0 \\
\hline & $\mathrm{As}^{3+}$ & 1.41 & 3.53 & 1.0 \\
\hline
\end{tabular}

\section{Physicochemical characterization of tannery and textile industries}

The physicochemical quality parameters including $\mathrm{pH}$, TDS, conductivity, salinity, BOD (biological oxygen demand) and COD (chemical oxygen demand) and other parameters of IWW were recorded and are presented in Table 1. Deep blue color was observed for both the effluent, and these highly colored compounds may cause significant harm to the environment. A relevant study reported that the deep blue-brown-black color might hinder the penetration of sunlight causing depletion in the rate of oxidation of the pollutants (Verma et al. 2008). The $\mathrm{pH}$ of the textile and tannery effluent was recorded as 6.85 and 7.4 , respectively, which is within the WHO (World Health Organization) permissible limit (6.0-8.5).

The electric conductivity (EC) of water is a measure of the ability of a solution to conduct an electric current; this ability depends on the dissolved solids, the presence of ions concentration, mobility and temperature of water. The conductivity of the water is one of the important parameters used to determine the suitability of water for irrigation. The conductivity of the textile and tannery effluent was recorded as 1370 and $1430 \mu \mathrm{S} / \mathrm{cm}$, respectively, which exceeded the upper limit prescribed by WHO $(1200 \mu \mathrm{S} /$ $\mathrm{cm}$ ). The total suspended solid (TSS) values of textile and tannery effluent ranged from 1250-1490 mg/L, which was far above the standard limits $(600 \mathrm{mg} / \mathrm{L})$ for effluent discharge and may cause damage to soil flora and fauna and lead to changes in soil porosity, soil texture and water holding capacity (Chowdhury and Fatema 2016). The BOD and COD values were found much higher than the WHO maximum permissible level. The TDS values of textile and tannery effluent were recorded as 912 and $851 \mathrm{mg} / \mathrm{L}$, lower than the WHO permissible limit $(2100 \mathrm{mg} / \mathrm{L})$. The salinity of the samples was relatively normal than other parameters. In addition, the average concentrations of heavy metals of tannery and textile effluents are also presented in Table 1.

Except cadmium (Cd) and nickel (Ni), all other metal and heavy metals were found higher than the WHO permissible limit. In case of textile effluent, substantially higher presence of copper $(25.14 \mathrm{mg} / \mathrm{L}), \mathrm{Zn}(49.08 \mathrm{mg} / \mathrm{L})$ and $\mathrm{Cr}(132.5 \mathrm{mg} / \mathrm{L})$ observed. On the contrary, 10-12-fold lower values of $\mathrm{Cu}, \mathrm{Zn}$ and $\mathrm{Cr}$ were observed throughout the study. Fe concentration of textile wastewater was recorded as $1.23 \mathrm{mg} / \mathrm{L}$, and this value was $14.57 \mathrm{mg} / \mathrm{L}$ in tannery effluent waste. The relative dominance of heavy metals in textile effluent was observed in the following sequence: $\mathrm{Cr}>\mathrm{Zn}>\mathrm{Cu}>\mathrm{Pb}>\mathrm{Ni}>\mathrm{Cd}>\mathrm{As}>\mathrm{Fe}$. On the other hand, in tannery effluent, the relative dominance of heavy metals was observed in the sequence: $\mathrm{Fe}>\mathrm{Cr}>\mathrm{As}$ $\mathrm{Zn}>\mathrm{Cd}>\mathrm{Cu}>\mathrm{Pb}>\mathrm{Ni}$. These study results demonstrated that the effluent water of both industries generated huge volume of wastewater containing various harmful chemicals, dyes and heavy metals, which severely impacted the environment.

\section{Microbial characterization of IWW}

Irrespective of types of bacteria, higher bacterial population was observed in textile effluent than in tannery wastewater. The textile effluent had high number of coliform bacteria which indicating the possible presence of fecal coliform and other pathogenic bacteria in the IWW (Table 2). In addition, the presence of heavy metal content was evident in effluent water analyzed and the presence of higher number of single and multiple metal-resistant bacteria was observed in the effluent water. The isolated strain was characterized as Bacillus cereus, C. freundii, P. aeruginosa and E. coli, and all of them found resistant to multiple heavy metals $\left(\mathrm{Cr}^{6+}+\mathrm{Pb}^{2+}+\mathrm{Cd}^{2+}\right)$ observed by surface plating the wastewater onto tryptic soya agar medium supplemented with heavy metals separately or in combination. Serratia liquefaciens was found to be resistant to $\mathrm{Cr}^{6+}$ but not to $\mathrm{Cd}^{2+}$ and $\mathrm{Pb}^{2+}$. In recent studies, Serratia $s p$. has been shown to be resistant to a concentration of $1,500 \mathrm{mg} \mathrm{Cr}^{6+} / \mathrm{L}$ (Zhang and Li 2011). Although other species of Serratia have been found to be resistant to $\mathrm{Cd}^{2+}$ and $\mathrm{Pb}^{2+}$ (Kono and Cho 2010), there is no recent evidence that shows $S$. liquefaciens is resistant to $\mathrm{Cd}^{2+}$ or $\mathrm{Pb}^{2+}$. Another isolated heavy metalresistant strain was Citrobacter freundii which is resistant to $\mathrm{Cr}^{6+}, \mathrm{Cd}^{2+}$ and $\mathrm{Pb}^{2+}$. In other studies, different strains 
Table 2 Distribution of bacterial population (log CFU/ml) of treated (MSP and WSP in combination) and control textile and tannery effluent water samples

\begin{tabular}{|c|c|c|c|c|c|c|c|c|}
\hline \multirow{3}{*}{$\begin{array}{l}\text { Name of microorgan- } \\
\text { isms analyzed }\end{array}$} & \multicolumn{4}{|c|}{ Textile wastewater } & \multicolumn{4}{|c|}{ Tannery wastewater } \\
\hline & \multicolumn{2}{|l|}{ Control } & \multicolumn{2}{|c|}{$\begin{array}{l}\text { Heavy metal }{ }^{\mathrm{a}} \text {-resistant } \\
\text { bacteria }\end{array}$} & \multicolumn{2}{|l|}{ Control } & \multicolumn{2}{|c|}{$\begin{array}{l}\text { Heavy metal }{ }^{\text {a }} \text {-resistant } \\
\text { bacteria }\end{array}$} \\
\hline & Untreated & Treated & Untreated & Treated & Untreated & Treated & Untreated & Treated \\
\hline TAB & $7.23 \pm 0.14$ & 3.67 & $3.14 \pm 0.09$ & 1.47 & $4.48 \pm 0.12$ & 2.11 & $2.95 \pm 0.07$ & 1.0 \\
\hline TCB & $3.38 \pm 0.04$ & 2.04 & $2.81 \pm 0.31$ & 1.0 & $4.04 \pm 0.09$ & 1.84 & $1.49 \pm 0.18$ & $<1.0$ \\
\hline E. coli & $3.11 \pm 0.09$ & $<1.0$ & $1.17 \pm 0.19$ & $<1.0$ & $2.67 \pm 0.21$ & $<1.0$ & $1.00 \pm 0.00$ & $<1.0$ \\
\hline Citrobacter sp. & $3.04 \pm 0.23$ & $<1.0$ & $1.22 \pm 0.07$ & $<1.0$ & $2.11 \pm 0.23$ & $<1.0$ & $1.04 \pm 0.23$ & $<1.0$ \\
\hline Bacillus sp. & $4.34 \pm 0.17$ & 1.85 & $2.56 \pm 0.22$ & 1.47 & $3.15 \pm 0.11$ & 1.84 & $1.69 \pm 0.16$ & $<1.0$ \\
\hline Serratia sp. & $2.75 \pm 0.18$ & $<1.0$ & $<1.0$ & $<1.0$ & $2.15 \pm 0.12$ & $<1.0$ & $<1.0$ & $<1.0$ \\
\hline Pseudomonas sp. & $3.07 \pm 0.14$ & $<1.0$ & ND & & $2.30 \pm 0.13$ & $<1.0$ & ND & \\
\hline
\end{tabular}

${ }^{\mathrm{a}}$ Resistant to $\mathrm{Cr}^{6+}, \mathrm{Pb}^{2+}$ and $\mathrm{Cd}^{2+}$ or in combination (50.0 ppm each); $\mathrm{ND}=$ not done; $<1.0=$ less than detection limit

of Citrobacter sp. have been shown to be resistant to $\mathrm{Cr}^{6+}$, $\mathrm{Cd}^{2+}$ and $\mathrm{Pb}^{2+}$ including $C$. freundii (Mohseni 2014). The resistance to multiple metal ion indicates that the resistance might have resulted from the presence of single or multiple genes present in their plasmids which may also confer antibiotic resistance to these bacteria (Yamina et al. 2014). The industrial effluents are enriched media to grow and spread microbial population, which are resistant to different metals (Khadivinia et al. 2014). The identification of bacteria resistance against different metals may provide a useful tool for the simultaneous monitoring of several toxic pollutants in the environment (Mohsenzadeh and Shahrokhi 2014). But heavy metal-resistant pathogenic bacteria may also confer health and environmental risk as metal resistance is often associated with antibiotic resistance. However, with proper handling these metal-resistant strains can be used as a bioremediation tool for the treatment of effluent from leather, textile and other industries handling heavy metals.

Thus, the results of this study revealed that the IWW was heavily contaminated with dyes, heavy metal and resistant microorganisms. Hence, discharge of this effluent into nearby river and pond directly can cause acute toxicity to the receiving water bodies. It therefore becomes essential to remove color and eliminate heavy metal, and these resistant bacteria from the tannery and textile effluent wastewater, so as to avoid the hazardous environmental effects. Several treatment methods have been employed to embark upon the problem of dye removal and metal degradation, but degradation becomes further more difficult for effluents containing dye matrix.

\section{Antibiotic resistivity pattern}

The microorganisms isolated from the IWW were seen multi-metal resistance at the concentration as high as
$50 \mathrm{mg} / \mathrm{L}$. In addition, all these multi-metal resistance bacteria were also found resistant to at least five antibiotics (amoxicillin, ampicillin, cefixime, ceftazidime and tazobactam) in common (Table 3 ).

\section{Dye removal and $\mathrm{Cr}^{+}$reduction using artificial challenge test}

When the LPEW was treated with MSP alone or in combination with WSP, $100 \%$ dye removal was observed within $4 \mathrm{~h}$ (percentage dye removal was calculated through the equation already mentioned in Sect. 2.7); at the same time, separate application of WSP was not found so effective (Figs. 1c, 2). However, total $\mathrm{Cr}^{+}$content was reduced to less than detection limit (lowest detection limit was $0.5 \mathrm{ppm}$ ) at 24 h (Fig. 3). Furthermore, addition of MSP and WSP into IWW resulted in clear solution in the upper layer and sludge layer at the bottom. To see which ingredients are responsible in removing the heavy metal $\left(\mathrm{Cr}^{6+}\right)$ from the laboratoryprepared dye solution, each effective concentration of MSP (0.8 gm/100 ml LPEW) and WSP (0.2 gm/100 ml LPEW) was also tested against the LPEW with 2.0-50.0 $\mathrm{ppm} \mathrm{Cr}^{+}$ and the results were presented in Table 4 and Fig. 3. It was observed that MSP alone was able to remove dye and heavy metal $\left(\mathrm{Cr}^{+}\right)$to non-detectable level. This finding is an agreement with the report of Ravikumar and Sheeja 2013, which stated that moringa seeds were capable of adsorbing $95 \%$ of copper, $93 \%$ of lead, $76 \%$ of cadmium and $70 \%$ of chromium from contaminated water. In addition, some recent research reported that heated shell waste possesses adsorbent capabilities to remove heavy metals from the liquid (Sawai et al. 2003; Rohim et al. 2014; El-Kassas and Mohamed 2014). 
Table 3 Resistance pattern of randomly selected bacterial isolates against multiple antibiotics and heavy metals

\begin{tabular}{|c|c|c|c|c|c|c|c|}
\hline \multicolumn{2}{|l|}{ Types of resistance determinants } & \multirow[t]{2}{*}{ Names of determinants } & \multicolumn{5}{|c|}{ Pattern of sensitivity } \\
\hline & & & E. coli & P. aeruginosa & C. freundii & S. liquefaciens & B. cereus \\
\hline \multirow[t]{20}{*}{ Antibiotics } & \multirow[t]{14}{*}{ Broad spectrum } & Amoxicillin $(10 \mu \mathrm{g})$ & $\mathrm{R}^{\mathrm{a}}$ & $\mathrm{R}$ & $\mathrm{R}$ & $\mathrm{R}$ & $\mathrm{R}$ \\
\hline & & Ampicillin $(10 \mu \mathrm{g})$ & $\mathrm{R}$ & $\mathrm{R}$ & $\mathrm{R}$ & $\mathrm{R}$ & $\mathrm{R}$ \\
\hline & & Azithromycin $(15 \mu \mathrm{g})$ & $\mathrm{R}$ & $\mathrm{S}$ & $\mathrm{R}$ & $\mathrm{R}$ & $\mathrm{S}$ \\
\hline & & Cefixime $(5 \mu \mathrm{g})$ & $\mathrm{R}$ & $\mathrm{R}$ & $\mathrm{R}$ & $\mathrm{R}$ & $\mathrm{R}$ \\
\hline & & Ceftazidime $(30 \mu \mathrm{g})$ & $\mathrm{R}$ & $\mathrm{R}$ & $\mathrm{R}$ & $\mathrm{R}$ & $\mathrm{R}$ \\
\hline & & Chloramphenicol $(30 \mu \mathrm{g})$ & $\mathrm{S}$ & $\mathrm{I}^{\mathrm{b}}$ & $\mathrm{S}^{\mathrm{c}}$ & $S$ & $S$ \\
\hline & & Ciprofloxacin $(5 \mu \mathrm{g})$ & $\mathrm{S}$ & $\mathrm{S}$ & $\mathrm{S}$ & $\mathrm{S}$ & I \\
\hline & & Erythromycin $(15 \mu \mathrm{g})$ & $\mathrm{R}$ & I & $\mathrm{R}$ & $\mathrm{R}$ & $\mathrm{S}$ \\
\hline & & Gentamicin $(10 \mu \mathrm{g})$ & I & $\mathrm{S}$ & $\mathrm{S}$ & $\mathrm{S}$ & $\mathrm{S}$ \\
\hline & & Nitrofurantoin $(300 \mu \mathrm{g})$ & $\mathrm{S}$ & $\mathrm{R}$ & I & $\mathrm{S}$ & $\mathrm{S}$ \\
\hline & & Rifampicin $(5 \mu \mathrm{g})$ & $\mathrm{R}$ & $\mathrm{R}$ & $\mathrm{R}$ & $\mathrm{R}$ & $\mathrm{R}$ \\
\hline & & Streptomycin $(10 \mu \mathrm{g})$ & $\mathrm{R}$ & I & I & I & $\mathrm{S}$ \\
\hline & & Tazobactam $(110 \mu \mathrm{g})$ & $\mathrm{R}$ & $\mathrm{R}$ & $\mathrm{R}$ & $\mathrm{R}$ & $\mathrm{R}$ \\
\hline & & Tetracycline $(30 \mu \mathrm{g})$ & I & $\mathrm{R}$ & I & $\mathrm{R}$ & $\mathrm{R}$ \\
\hline & \multirow[t]{6}{*}{ Narrow spectrum } & Aztreonam $(30 \mu \mathrm{g})$ & $\mathrm{R}$ & $\mathrm{R}$ & I & $\mathrm{R}$ & $\mathrm{NRU}^{\mathrm{d}}$ \\
\hline & & Polymyxin $(300 \mu \mathrm{g})$ & $\mathrm{S}$ & $\mathrm{S}$ & $\mathrm{S}$ & $\mathrm{S}$ & NRU \\
\hline & & Kanamycin $(30 \mu \mathrm{g})$ & $\mathrm{R}$ & $\mathrm{R}$ & I & I & NRU \\
\hline & & Nalidixic acid $(30 \mu \mathrm{g})$ & $\mathrm{R}$ & $\mathrm{R}$ & $\mathrm{S}$ & $\mathrm{S}$ & NRU \\
\hline & & Novobiocin $(30 \mu \mathrm{g})$ & NRU & NRU & NRU & NRU & $\mathrm{S}$ \\
\hline & & Bacitracin $(10 \mu \mathrm{g})$ & NRU & NRU & NRU & NRU & $\mathrm{R}$ \\
\hline \multirow[t]{4}{*}{ Heavy metals (50 ppm each) } & & $\mathrm{Cr}^{6+}$ & $\mathrm{R}$ & $\mathrm{R}$ & $\mathrm{R}$ & $\mathrm{R}$ & $\mathrm{R}$ \\
\hline & & $\mathrm{Cd}^{2+}$ & $\mathrm{R}$ & $\mathrm{R}$ & $\mathrm{R}$ & $\mathrm{R}$ & $\mathrm{R}$ \\
\hline & & $\mathrm{Pb}^{2+}$ & $\mathrm{R}$ & $\mathrm{R}$ & $\mathrm{R}$ & $\mathrm{S}$ & $\mathrm{R}$ \\
\hline & & $\mathrm{Cr}^{6+}+\mathrm{Cd}^{2+}+\mathrm{Pb}^{2+}$ & $\mathrm{R}$ & $\mathrm{R}$ & $\mathrm{R}$ & $\mathrm{S}$ & $\mathrm{R}$ \\
\hline
\end{tabular}

\section{Dye discoloration, heavy metal reduction and inactivation of bacteria using combined biological materials}

The use of plant materials as natural coagulants to clarify turbidity of wastewaters is of common practice since ancient times. Of all plant material investigated, seeds of Moringa oleifera are one of the most effective sources of primary coagulant for water treatment (Oluduro and Aderiye 2007; Ali et al. 2009). In addition, Hou et al. (2016) reported that use of marine shell waste powder, alkaline in nature and calcium-based materials with high hygroscopicity was proved to remove phosphorous, toxic metallic ions, sulfur dioxide and adsorption of toxic dyes from wastewater which can contribute to preserving water ecosystems and assist with waste discharge problems (Hou et al. 2016). Thus, application of MSP or WSP singly was able to eliminate dyes and heavy metal with MSP; however, WSP was able to reduce toxic metal and eliminate bacteria. Hence, combined application was able to eliminate dyes, absorb up to $50 \mathrm{mg} / \mathrm{L}$ of $\mathrm{Cd}^{2+}, \mathrm{Pb}^{2+}$ and $\mathrm{Cr}^{6+}$ and eliminate bacteria, when exposed for a $24-\mathrm{h}$ period to effluent wastewater. This result is an agreement with the results of another study, which reported that heated egg shell removes $95 \%$ of chromium at an optimum $\mathrm{pH} 5.0$ and $1.45 \mathrm{mg} / \mathrm{g}$ of maximum adsorption capacity (Daraei et al. 2015). Thus, combination of effective concentration of MSP and WSP was used to remove color (Figs. 1,2); heavy metal (Table 4); and eliminate bacteria (Table 2) from effluent water efficiently. However, despite efficient removal of dyes, heavy metal and pathogens from IWW, the sludge volume increased in the waste effluent which contains all the removed heavy metal, dyes and resistant microbial cells along with moringa seed powder and marine shell. Therefore, only water can be reused or discharged into the environment from the industrial wastewater through these techniques, but sludge disposal still remains a challenge, and land disposal or dumping 


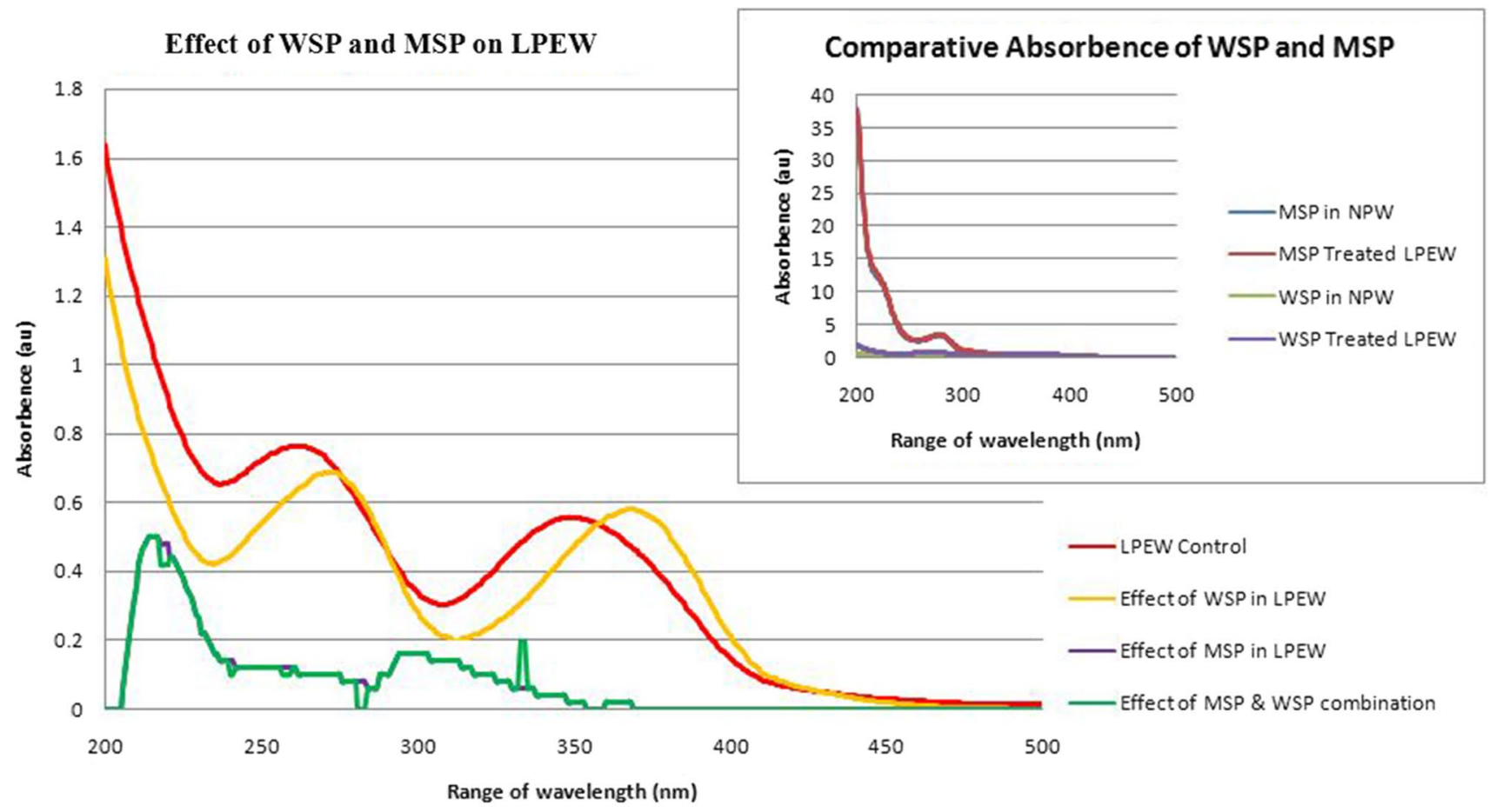

Fig. 2 Effectiveness of MSP and WSP to remove dye and heavy metal from LPEW
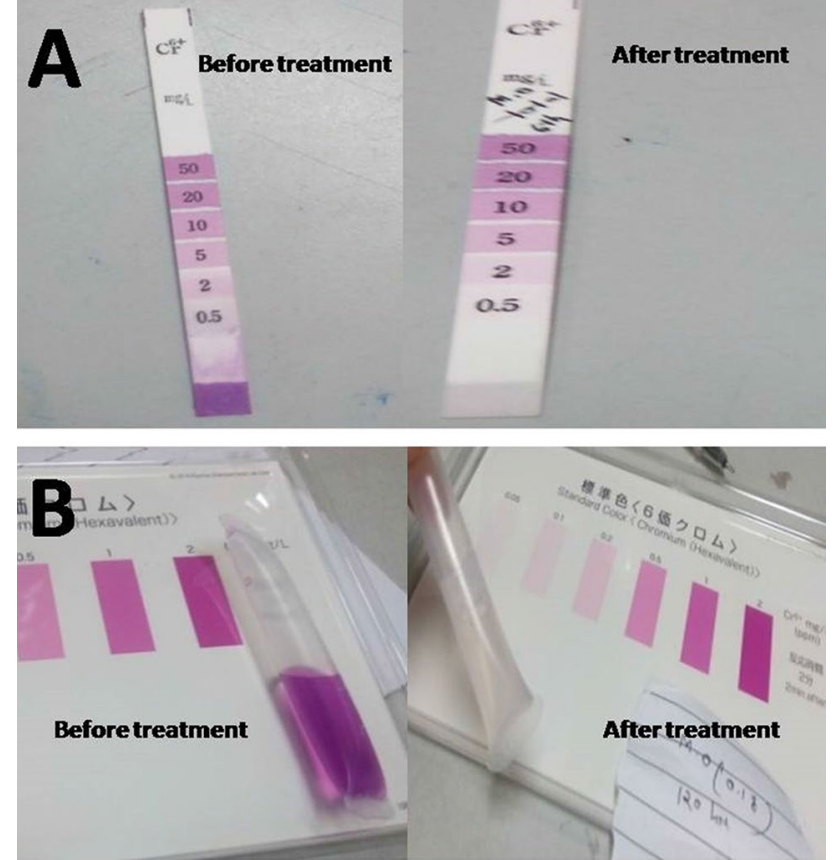

Fig. 3 MSP and WSP treatment in eliminating $\mathrm{Cr}^{6+}$ from effluent water; color bands mean the presence of $\mathrm{Cr}^{+}$, where transparent color indicates the level of $\mathrm{Cr}+$ below detection limit $\left(\mathbf{a ~} \mathrm{Cr}^{6+}\right.$ test strips; $\mathbf{b}$ $\mathrm{Cr}^{+}$test kits) in the ocean may contaminate underground water or may destroy sea habitat, respectively. On the other hand, incineration completely evaporates the moisture and converts the organic solids into inert ash, but the heavy metal still remains in the inert ash because heavy metal cannot be decayed, but can convert from one form to another only.

\section{Conclusion}

The discharge of dyes in the environment is a matter of concern for both toxicological and esthetical point of view, and these study results demonstrated that combined application of MSP (0.8\%) and WSP (0.2) was able to effectively remove dye (up to $35 \mathrm{ppm}$ ), heavy metal (up to $50 \mathrm{ppm}$ $\mathrm{Cr}^{6+}$ ) and 3-7 $\log \mathrm{CFU} / \mathrm{ml}$ of microbial contaminants simultaneously from the effluent water within $24 \mathrm{~h}$. Hence, these two bio-sorbents could be applicable in IWW treatment of textile and tannery industries before being discharged into the environment. Therefore, only water can be discharged into the environment from the industrial wastewater through these techniques, but sludge disposal still remains a challenge. 
Table 4 Effectiveness of bio-sorbant materials to remove $\mathrm{Cr}^{+}$from LPEW

\begin{tabular}{|c|c|c|c|c|c|c|c|c|c|}
\hline \multirow[t]{2}{*}{ Treatment time } & \multicolumn{3}{|c|}{$\mathrm{Cr}^{6+}(2.0 \mathrm{ppm})$} & \multicolumn{3}{|c|}{$\mathrm{Cr}^{6+}(50.0 \mathrm{ppm})$} & \multicolumn{3}{|c|}{$\mathrm{Cr}^{6+}$ and $\mathrm{Cr}^{3+}(2.0 \mathrm{ppm})$} \\
\hline & $\begin{array}{l}\text { Treatment } \\
\text { with MSP }\end{array}$ & $\begin{array}{l}\text { Treatment } \\
\text { with WSP }\end{array}$ & $\begin{array}{l}\text { Treatment } \\
\text { combined }\end{array}$ & $\begin{array}{l}\text { Treatment } \\
\text { with MSP }\end{array}$ & $\begin{array}{l}\text { Treatment } \\
\text { with WSP }\end{array}$ & $\begin{array}{l}\text { Treatment } \\
\text { combined }\end{array}$ & $\begin{array}{l}\text { Treatment } \\
\text { with MSP }\end{array}$ & $\begin{array}{l}\text { Treatment } \\
\text { with WSP }\end{array}$ & $\begin{array}{l}\text { Treatment } \\
\text { combined }\end{array}$ \\
\hline $\begin{array}{l}\text { Immediately } \\
\text { after treatment }\end{array}$ & 1.5 & 2.0 & 1.5 & 20 & 50 & 20 & 1.5 & 2.0 & 1.5 \\
\hline $24 \mathrm{~h}$ & $<0.05$ & 2.0 & $<0.05$ & $<0.5$ & 50 & $<0.5$ & $<0.05$ & 2.0 & $<0.05$ \\
\hline $48 \mathrm{~h}$ & $<0.05$ & 2.0 & $<0.05$ & $<0.5$ & 50 & $<0.5$ & $<0.05$ & 2.0 & $<0.05$ \\
\hline $72 \mathrm{~h}$ & $<0.05$ & 2.0 & $<0.05$ & $<0.5$ & 50 & $<0.5$ & $<0.05$ & 2.0 & $<0.05$ \\
\hline Fourth day & $<0.05$ & 2.0 & $<0.05$ & $<0.5$ & 50 & $<0.5$ & $<0.05$ & 2.0 & $<0.05$ \\
\hline Fifth day & $<0.05$ & 2.0 & $<0.05$ & $<0.5$ & 50 & $<0.5$ & $<0.05$ & 2.0 & $<0.05$ \\
\hline Sixth day & $<0.05$ & 2.0 & $<0.05$ & $<0.5$ & 50 & $<0.5$ & $<0.05$ & 2.0 & $<0.05$ \\
\hline Seventh day & $<0.05$ & 2.0 & $<0.05$ & $<0.5$ & 50 & $<0.5$ & $<0.05$ & 2.0 & $<0.05$ \\
\hline
\end{tabular}

Open Access This article is licensed under a Creative Commons Attribution 4.0 International License, which permits use, sharing, adaptation, distribution and reproduction in any medium or format, as long as you give appropriate credit to the original author(s) and the source, provide a link to the Creative Commons licence, and indicate if changes were made. The images or other third party material in this article are included in the article's Creative Commons licence, unless indicated otherwise in a credit line to the material. If material is not included in the article's Creative Commons licence and your intended use is not permitted by statutory regulation or exceeds the permitted use, you will need to obtain permission directly from the copyright holder. To view a copy of this licence, visit http://creativecommons.org/licenses/by/4.0/.

\section{References}

Abbas HS, Ismail MI, Mostafa MT, Sulaymon HA (2014) Biosorption of heavy metals: a review. J Chem Sci Technol 3:74-102

Ahmed S, Akand NR, Islam MT, Bari ML (2015) Effectiveness of scallop powder ice in reducing bacterial load on fresh whole fish and in the melted ice water. LWT-Food Sci Technol 64(1):270-274

Ahmed S, Zaman S, Ahmed R, Uddin MN, Acedo A Jr, Bari ML (2017) Effectiveness of non-chlorine sanitizers in improving the safety and quality of fresh betel leaf. LWT-Food Sci Technol 78:77-81

Aho IM, Lagasi JE (2012) A new water treatment system using Moringa oleifera seed. Am J Sci Ind Res 3(6):487-492

Akpor OB, Muchie M (2010) Remediation of heavy metals in drinking water and wastewater treatment systems: processes and applications. Int J Phys Sci 5(12):1807-1817

Alalewi A, Jiang C (2012) Bacterial influence on textile wastewater decolorization. J Environ Prot 3(8):889

Ali EN, Muyibi SA, Salleh HM, Salleh MRM, Alam M (2009) Moringa oleifera seeds as natural coagulant for water treatment. In: Thirteenth international Egyptian water technology conference

Chowdhury MA, Fatema KJ (2016) Review of renewable biosorbent from coir pith waste for textile effluent treatment. Int J Text Sci 5(6): 132-140

Daraei H, Mittal A, Noorisepehr M, Mittal J (2015) Separation of chromium from water samples using eggshell powder as a low-cost sorbent: Kinetic and thermodynamic studies. Desalination Water Treat 53(1):214-220
Dorthy CAM, Sivaraj R, Venckatesh R (2012) Decolorization of reactive violet-2RL dye by aspergillus flavus and aspergillus fumigatus from textile sludge. Int Res J Environ Sci 1:8-12

El-Kassas HY, Mohamed LA (2014) Bioremediation of the textile waste effluent by Chlorella vulgaris. Egypt J Aquat Res 40(3):301-308

Ezaka E, Anyanwu CU (2011) Chromium (VI) tolerance of bacterial strains isolated from sewage oxidation ditch. Int J Environ Sci 1(7):17-25

Eze VC, Ananso JD (2014) Assessment of water purification potential of Moringa oleifera seeds. Int J Microbiol Appl 1(2):23-30

Girma G (2015) Microbial bioremediation of some heavy metals in soils: an updated review. Indian J Sci Res 6(1):147

Hou Y, Shavandi A, Carne A, Bekhit AA, Ng TB, Cheung RCF, Bekhit AEDA (2016) Marine shells: Potential opportunities for extraction of functional and health-promoting materials. Crit Rev Environ Sci Technol 46(11-12):1047-1116

Ismail YA (2010) Synthesis and characterization of electrically conducting poly-o-methoxyaniline $\mathrm{Zr}(1 \mathrm{~V})$ molybdate $\mathrm{Cd}$ (II) selective composite cation-exchanger. Desalination 250(2):523-529

Islam MM, Mahmud K, Faruk O, Billah S (2011) Assessment of environmental impacts for textile dyeing industries in Bangladesh. In: International conference on green technology and environmental conservation, pp 173-181.

Jeon DJ, Yeom SH (2009) Recycling wasted biomaterial, crab shells, as an adsorbent for the removal of high concentration of phosphate. Biores Technol 100(9):2646-2649

Kant R (2012) Textile dyeing industry an environmental hazard. Nat Sci 4(1):22-26

Khadivinia E, Sharafi H, Hadi F, Zahiri HS, Modiri S, Tohidi A, Noghabi KA (2014) Cadmium biosorption by a glyphosatedegrading bacterium, a novel biosorbent isolated from pesticidecontaminated agricultural soils. J Ind Eng Chem 20(6):4304-4310

Koo SY, Cho KS (2010) Characterization of Serratia sp. K1RP-49 for application to the Rhizoremediation of heavy metals. Surv Sustain 3-13.

Lim JY, Mubarak NM, Abdullah EC, Nizamuddin S, Khalid M (2018) Recent trends in the synthesis of graphene and graphene oxide based nanomaterials for removal of heavy metals-A review. $\mathbf{J}$ Ind Eng Chem 66:29-44

Mangale SM, Chonde SG, Jadhav AS, Raut PD (2012) Study of Moringa oleifera (drumstick) seed as natural absorbent and antimicrobial agent for river water treatment. J Nat Prod Plant Resour 2(1):89-100 
Mohseni M (2014) Bioremediation activity of $\mathrm{Pb}$ (II) resistance Citrobacter sp. MKH2 isolated from heavy metal contaminated sites in Iran. J Sci Islam Republ Iran 25(2): 105-110

Mohsenzadeh F, Shahrokhi F (2014) Biological removing of Cadmium from contaminated media by fungal biomass of Trichoderma species. J Environ Health Sci Eng 12(1):102

Nabi SA, Bushra R, Al-Othman ZA, Naushad Mu (2011) Synthesis, characterization and analytical applications of a new composite cation exchange material Acetonitrile stannic(IV) selenite: adsorption behavior of toxic metal ions in nonionic surfactant medium. Sep Sci Techn 46(5):847-857

Nayak MC, Isloor AM, Lakshmi B, Marwani HM, Khan I (2019) Polyphenylsulfone/multiwalled carbon nanotubes mixed ultrafiltration membranes: Fabrication, characterization and removal of heavy metals $\mathrm{Pb}^{2+}, \mathrm{Hg}^{2+}$, and $\mathrm{Cd}^{2+}$ from aqueous solutions. Arab J Chem 13(3):4661-4672

Oak U, Ghattargi V, Pawar S, Bhole B (2016) Degradation of Drimarene Red, a reactive textile dye by an extremophilic Bacillus sp. isolated from fresh water. Int J Appl Pure Sci Agric 2:105-113

Oluduro AO, Aderiye BI (2007) Impact of Moringa seed extract on the physicochemical properties of surface and undergroundwater. Int J Biol Chem Sci 1(4):244-249

Padhi BS (2012) Pollution due to synthetic dyes toxicity and carcinogenicity studies and remediation. Int J Environ Sci 3(3):940

Pandey A, Singh P, Iyengar L (2007) Bacterial decolorization and degradation of azo dyes. Int Biodeterior Biodegr 59(2):73-84

Patel KP, Tank SK, Patel KM, Patel P (2013) Removal of cadmium and zinc ions from aqueous solution by using two type of husks. APCBEE Proc 5:141-144

Priya ES, Selvan PS (2017) Water hyacinth (Eichhornia crassipes)-An efficient and economic adsorbent for textile effluent treatment-a review. Arab J Chem 10:3548-3558

Ravikumar K, Sheeja AK (2013) Heavy metal removal from water using Moringa oleifera seed coagulant and double filtration. Contrib Pap 9

Rodrigues CS, Madeira LM, Boaventura RA (2013) Treatment of textile dye wastewaters using ferrous sulphate in a chemical coagulation/flocculation process. Environ Technol 34(6):719-729

Rohim R, Ahmad R, Ibrahim N, Hamidin N, Abidin CZA (2014) Characterization of calcium oxide catalyst from eggshell waste. Adv Environ Biol 8(22):35-38
Sajidu SMI, Henry EMT, Persson I, Masamba WRL, Kayambazinthu $\mathrm{D}$ (2006) $\mathrm{pH}$ dependence of sorption of $\mathrm{Cd}^{2+}, \mathrm{Zn}^{2+}, \mathrm{Cu}^{2+}$ and $\mathrm{Cr}^{3+}$ on crude water and sodium chloride extracts of Moringa stenopetala and Moringa oleifera. Afr J Biotechnol 5(23)

Sawai J, Miyoshi H, Kojima H (2003) Sporicidal kinetics of Bacillus subtilis spores by heated scallop shell powder. J Food Prot 66(8):1482-1485

Taiwo AS, Adenike K, Aderonke O (2020) Efficacy of a natural coagulant protein from Moringa oleifera (Lam) seeds in treatment of Opa reservoir water, Ile-Ife. Nigeria. Heliyon 6(1):e03335. https ://doi.org/10.1016/j.heliyon.2020.e03335

Valverde KC, de Souza Paccola EA, Pomini AM, Yamaguchi NU, Bergamasco R (2018) Combined water treatment with extract of natural Moringa oleifera Lam and synthetic coagulant. Revista Ambiente \& Água 13(3):e2135. https://doi.org/10.4136/ ambi-agua.2135

Verma T, Ramteke PW, Garg SK (2008) Quality assessment of treated tannery wastewater with special emphasis on pathogenic E. coli detection through serotyping. Environ Monit Assess 145(1-3):243-249

Wang H, Yuan X, Zeng G, Leng L, Peng X, Liao K, Xiao Z (2014) Removal of malachite green dye from wastewater by different organic acid-modified natural adsorbent: kinetics, equilibriums, mechanisms, practical application, and disposal of dye-loaded adsorbent. Environ Sci Pollut Res 21(19):11552-11564

Yamina B, Tahar B, Lila M, Hocine H, Laure FM (2014) Study on cadmium resistant-bacteria isolated from hospital wastewaters. Adv Biosci Biotechnol 5(08):718

Zaman S, Begum A, Rabbani KS, Bari L (2017) Low cost and sustainable surface water purification methods using Moringa seeds and scallop powder followed by bio-sand filtration. Water Sci Technol Water Supply 17(1):125-137

Zhang K, Li F (2011) Isolation and characterization of a chromiumresistant bacterium Serratia sp. Cr-10 from a chromate-contaminated site. Appl Microbiol Biotechnol 90(3):1163-1169

Publisher's Note Springer Nature remains neutral with regard to jurisdictional claims in published maps and institutional affiliations. 